\title{
Integrin-mediated action of insulin-like growth factor binding protein-2 in tumor cells
}

\author{
B S Schütt, M Langkamp, U Rauschnabel'1, M B Ranke and M W Elmlinger \\ Pediatric Endocrinology Section, University Children's Hospital, 72076 Tuebingen, Germany and ${ }^{1}$ Olga Hospital, 70176 Stuttgart, Germany \\ (Requests for offprints should be addressed to Martin W Elmlinger, Pediatric Endocrinology Section, Children's Hospital, Hoppe-Seyler-Strasse 1, \\ D-72076 Tuebingen/Germany; Email: martin.elmlinger@med.uni-tuebingen.de) \\ (B S Schütt and M Langkamp contributed equally to this work)
}

\begin{abstract}
The neoplastic production of the insulin-like growth factor binding protein (IGFBP)-2 often correlates with tumor malignancy and aggressiveness. Since IGFBP-2 contains an RGD motif in its C-terminus, it was hypothesized that this protein may act independently of IGF on tumor cells through integrins. To investigate this, integrin binding, intracellular signaling and the impact of IGFBP-2 on cell adhesion and proliferation were examined in two tumor cell lines. In tracer displacement studies, up to $30 \%$ of the added ${ }^{125}$ |-hIGFBP-2 specifically bound to the cells. Bound ${ }^{125}$ |-hIGFBP-2 was reversibly displaced by IGFBP-2, IGFBP-1 and RGD-(Gly-Arg-Asp)-containing peptides, but not by IGFBP-3, -4, -5, -6 and RGE-(Gly-Arg-Glu)-containing peptides. Blocking with antibodies directed against different integrins and with fibronectin demonstrated that IGFBP-2 cell surface binding is specific for $\alpha 5 \beta 1$-integrin. Incubation of IGFBP-2 with equimolar quantities of IGF-I and IGF-II annihilated RGD-specific binding. IGFBP-2 binding at the cell surface led to dephosphorylation of the focal adhesion-kinase (FAK) of up to $37 \%(P<0.01)$, and of the p42/44 MAP-kinases of up to $40 \%(P<0.01)$. In addition, IGFBP-2 promoted de-adhesion of the cells dose-dependently by up to $30 \%(P<0.05)$, and reduced proliferation by $24 \%(P<0.01)$. Since one of the cell lines used does not express a functional IGF-I receptor, these data demonstrate that IGFBP-2 can act in an IGF-independent manner, at least in part by an interaction with $\alpha 5 \beta 1$-integrin.
\end{abstract}

Journal of Molecular Endocrinology (2004) 32, 859-868

\section{Introduction}

Insulin-like growth factor binding proteins (IGFBPs), as a part of the insulin-like growth factor (IGF) system, are important in the regulatory network, controlling essential cellular processes such as proliferation, differentiation, apoptosis and cell migration (Clemmons 1997, Firth \& Baxter 2002). Alterations in the expression of components of this balanced system can cause dysregulation of cellular homeostasis, which may lead to cancer.

IGFBP-2 has been reported to be markedly overexpressed in many tumors and tumor cell lines (Kanety et al. 1993, Boulle et al. 2001, Elmlinger et al. 2001a). This elevated expression of IGFBP-2 might be promoted by autocrine/paracrine stimulation via IGF-II- and/or pro-IGF-forms, which tumors often secrete in large quantities (Yang et al. 1996, Duguay et al. 1998, Elmlinger et al. 1999, Elmlinger et al. 2001b). Thus, it is assumed that elevation of the IGFBP-2 production is part of a mechanism to compensate for the mitogenic and antiapoptotic effects of tumor-derived IGFs.

Increasing evidence points to a direct role of IGFBP-2 in tumor malignancy. In tumor cells, overexpression of IGFBP-2 promotes growth tolerance against metabolic stress, while hindering apoptosis in these cells (Oh \& Rosenfeld 1999, Hoeflich et al. 2000a). Clinical observations on patients with tumors of the brain, adrenal cortex, prostate and other organs further show the direct effects of IGFBP-2 on tumor progression (Miller 1994, Ho \& Baxter 1997, Boulle et al. 2001, Elmlinger et al. 2001a). All of these studies reveal a clear relationship between the degree of clinical malignancy and the degree of expression, or serum levels, of IGFBP-2.

The search for the mechanism of a direct IGFBP-2 cellular effect led to the observation that IGFBP-2 can bind to glycosaminoglycans of the 
extracellular matrix (Arai et al. 1995). However, no biologic effect after binding could be detected. Russo et al. (1997) confirmed binding of IGFBP-2 to specific proteoglycans in the olfactory bulb of the rat. In addition, they also showed that IGFBP-2 is proteolysed directly on the surface of specific cells of neuronal origin and that one fragment maintained binding ability (Russo et al. 1999). Thus, a proliferative effect of IGFBP-2 could be explained by the transport of IGFs to cell surfaces after binding to proteoglycans in the proximity of the IGF-I receptor.

It is known that IGFBP-2 and IGFBP-1 molecules contain a C-terminal RGD (Gly-ArgAsp) peptide motif, which predestines them to binding to and signaling through integrins. An early event in integrin signaling is marked by alterations in the phosphorylation status of the focal adhesion kinase (FAK), which can be triggered by RGD-containing peptides. This pathway is involved in the regulation of cell migration, apoptosis and cell growth (Ruoslahti 1999).

We hypothesized that IGFBP-2 can influence the adhesion, proliferation and migration of tumor cells by way of integrin binding, as was shown for IGFBP-1 (Jones et al. 1993, Perks et al. 1999). First, we examined the binding of IGFBP-2 to the surface of tumor cell lines and the biochemical nature of the IGFBP-2 binding site. We used two highly malignant, solid tumor cell lines to distinguish between IGF-dependent and non-IGF-dependent effects: the Ewing sarcoma cell line A673, which produces IGFBP-2 and expresses the IGF-I receptor, and the breast cancer cell line Hs578T, which neither produces IGFBP-2 nor expresses a functional IGF-I receptor (Gill et al. 1997). We then analyzed the effects of the binding of IGFBP-2 on the signal transduction of integrins; that is, on the phosphorylation level of FAK and p42/44 mitogen-associated protein kinase (MAPK). In order to assess the biologic significance of the cell-surface binding and integrin signaling of IGFBP-2, we investigated its effect on cell proliferation and adhesion.

\section{Materials and methods}

\section{Cell culture}

The Ewing sarcoma cell line A673 was obtained from the American Type Culture Collection (No.
CRL-7910 and CCL-86 ATCG, Rockville, MD, USA) and cultured in RPMI 1640 medium supplemented with penicillin/streptomycin $(100 \mu \mathrm{g} / \mathrm{ml})$ and $10 \%$ fetal calf serum (FCS) at $37^{\circ} \mathrm{C}$ in $5 \% \mathrm{CO}_{2}$. The breast cancer cell line Hs578T was purchased from the European Collection of Cell Cultures (No. 86082104 ECACG, Porton Down, Salisbury, UK) and cultured in DMEM/HamsF12 (Seromed, Berlin, Germany) supplemented with penicillin/ streptomycin $(100 \mu \mathrm{g} / \mathrm{ml}), 2 \mathrm{mM}$ L-glutamine and $10 \%$ FCS at $37{ }^{\circ} \mathrm{C}$ in $5 \% \mathrm{CO}_{2}$.

Prior to analysis of detachment and analysis of FAK and MAPK phosphorylation, the A673 and Hs578T cells were incubated in serum-free media (SFM) supplemented with transferrin $(50 \mu \mathrm{g} / \mathrm{ml})$, insulin $(2 \mathrm{ng} / \mathrm{ml})$ and sodium selenite $(6 \mathrm{ng} / \mathrm{ml})$, all from Merck (Darmstadt, Germany). Cells were counted using the automated Advia 120 cell counter (Bayer, Leverkusen, Germany).

\section{Tracer displacement studies}

To study the IGFBP-2 cell-surface binding, A673 or Hs578T cells were trypsinized and washed carefully in PBS, and equal numbers of cells $\left(5 \times 10^{6}\right)$ were resuspended in $250 \mu \mathrm{lBS}$ in $5 \mathrm{ml}$, conical, polycarbonate tubes; in the case of competitive antibody incubation, $1 \%(\mathrm{w} / \mathrm{v})$ BSA was added. These solutions were then incubated with ${ }^{125}$ I-labeled hIGFBP-2 (50 000 c.p.m.; specific activity $68 \mu \mathrm{Ci} / \mu \mathrm{g})$, in the presence of various amounts of different unlabeled proteins and antibodies for displacement studies, as indicated in figures and legends: hIGFBP-1 (purified from amniotic fluid); rhIGFBP-2 (gift from Sandoz, Basel, Switzerland); rhIGFBP-3, rhIGFBP-4, rhIGFBP-5 and rhIGFBP-6 (purchased from Austral Biologicals, San Ramon/CA, USA); insulin, actin and fibronectin (from Hoffman La Roche, Basel, Switzerland); albumin and synthetic RGD and RGE (Gly-Arg-Glu) heptapeptides (from Sigma, Deisenhofen, Germany); anti- $\alpha 5 \beta 1$-integrin and anti- $\alpha v \beta 3$ integrin antibody (both from Becton Dickinson, San Diego, CA, USA); and anti- $\alpha 1 \beta 1$ integrin antibody (from Serotec, Duesseldorf, Germany). The cells were gently agitated for $2 \mathrm{~h}$ at room temperature and washed twice with $500 \mu \mathrm{l}$ PBS (centifugation steps at $200 \boldsymbol{g}$ ), the resultant cell pellet-associated radioactivity was analyzed by $\gamma$-counter (Berthold, Bad Wildbad, Germany), 
unspecific binding (incubation without cells) were substracted, and data were calculated relative to an untreated control or a control treated with anti-goat rabbit immunoglobulin G (IgG) (SigmaAldrich, Taufkirchen, Germany) in the case of antibody incubation.

\section{Cell detachment assays}

Hs578T cells $\left(5 \times 10^{4}\right)$ were seeded and cultured to 80-90\% confluency in polystyrene six-well plates (Nunc, Denmark) and serum-starved for $24 \mathrm{~h}$. Thereafter, the cells were incubated for $24 \mathrm{~h}$ with either rhIGFBP-2 (0, 200-800 ng/ml), RGE peptide or RGD peptide $(100 \mu \mathrm{g} / \mathrm{ml}$ each). Following this incubation period, the number of non-adherent cells in the supernatant was determined with the automated cell counter, as mentioned above.

\section{Proliferation assays}

Hs578T cells $\left(2 \times 10^{4}\right)$ per well were seeded into 96-well plates (BD Bioscience, San Diego, CA, USA) and cultured in complete media in the presence of the peptides listed in the legend of figure 5. After $24 \mathrm{~h}, 1 \mu \mathrm{Ci}\left[{ }^{3} \mathrm{H}\right]$ thymidine was added, and incubation was continued for another $72 \mathrm{~h}$. Cells were then harvested and immobilized by the Harvester 96 (TOMTEC, Hamden, CT, USA) on a nitrocellulose membrane and washed five times with water. The membrane was wrapped tightly in polyethylene foil, and after addition of $2 \mathrm{ml}$ of scintillation fluid (Betaplate Scint, Fison Chemicals, Loughborough, UK), the radioactivity incorporated in each well was counted by a 96-well beta-counter (MicroBeta 1450, Wallac, Milton Keynes, UK).

\section{Cell stimulation}

A673 and Hs578T cells (each $1 \times 10^{5}$ ) were seeded into polystyrene culture dishes $5 \mathrm{~cm}$ in diameter (BD Bioscience) with $5 \mathrm{ml}$ complete media for $24 \mathrm{~h}$. The media were replaced by serum-free media $(5 \mathrm{ml})$, and the cells were incubated for another $12 \mathrm{~h}$. Thereafter, the A673 cells were incubated with anti-IGFBP-2 antibody, or, in the case of Hs578T cells, with IGFBP-2 protein for $30 \mathrm{~min}$ at $37^{\circ} \mathrm{C}$, for analysis of FAK phosphorylation. For analysis of MAPK phosphorylation, both cell lines were stimulated with rhIGFBP-2 at the concentrations indicated for $5 \mathrm{~min}$. Immediately after stimulation, the cells were washed with PBS and lysed with $0.2 \mathrm{ml}$ lysis buffer $(10 \mathrm{mM}$ Tris-HCl, $5 \mathrm{mM}$ EDTA, $50 \mathrm{mM} \mathrm{NaCl}, 30 \mathrm{mM}$ sodium pyrophosphate, $50 \mathrm{mM}$ sodium fluoride, $100 \mu \mathrm{M}$ sodium orthovanadate, complete-EDTA free, pH 7·6; Hoffmann La Roche, Basel, Switzerland) and incubated for $15 \mathrm{~min}$ at $4{ }^{\circ} \mathrm{C}$. The cell lysates were centrifuged at $20000 \boldsymbol{g}$ for $15 \mathrm{~min}$ and the supernatants used for further analysis.

\section{Immunoprecipitation}

For immunoprecipitation, $0.5 \mathrm{mg}$ of total protein, measured by the BCA test (Pierce, Rockford, IL, USA) was incubated with $4 \mu \mathrm{g}$ of anti-FAK- or antiphosphotyrosine antibody clone PY99 (BD, San Diego, CA, USA) in a total volume of $200 \mu \mathrm{l}$. After $2 \mathrm{~h}$ of incubation at $4^{\circ} \mathrm{C}, 10 \mu \mathrm{g}$ of protein A-Sepharose (Amersham Pharmacia Biotech, Buckinghamshire, UK) were added, and incubation was continued for $1 \mathrm{~h}$. The precipitated antigen/ antibody complex was then pelleted at $20000 \boldsymbol{g}$ for $5 \mathrm{~min}$. The resultant pellet was washed three times with $250 \mu \mathrm{l}$ lysis buffer and finally resuspended in $30 \mu \mathrm{l}$ SDS-sample buffer containing $1 \% \quad \beta$-mercaptoethanol (Sigma, Deisenhofen, Germany).

\section{Western immunoblotting}

The soluble proteins of the cell lysates $(30-50 \mu \mathrm{g}$ total protein), or the resuspended immunoprecipitate, were separated by SDS-PAGE (10\%) for $1 \mathrm{~h}$ at $200 \mathrm{~V}$, and transferred onto a PVDF membrane (0.45 $\mu \mathrm{m}$; Millipore, Dassel, Germany) by semi-dry blot (Bio-Rad, Hercules, CA, USA) using CAPS buffer (10 mM CAPS, 0.005\% SDS and 1\% methanol, $\mathrm{pH} 10 \cdot 6)$ at $1 \mathrm{~mA} / \mathrm{cm}^{2}$. After blocking for $1 \mathrm{~h}$ in TBS-T (0.01 M Tris, $0 \cdot 15 \mathrm{M} \mathrm{NaCl}$ and $0 \cdot 1 \%$ Tween 20, pH 7.6) containing $10 \%$ Rotiblock (Roth, Germany), the membrane was incubated with either anti-FAK antibody ( 1 in 2000), antiphosphotyrosine antibody clone PY99 (1 in 2000), anti-MAPK antibody (1 in 1000) or antiphosphoMAPK antibody ( 1 in 1000; all from BD Bioscience) overnight at $4{ }^{\circ} \mathrm{C}$ in blocking buffer. After washing of the membrane three times for $15 \mathrm{~min}$ in TBS-T, the secondary antibody (antimouse IgG horseradish peroxidase conjugate, 1 in 
2000, Amersham Pharmacia, Buckinghamshire, $\mathrm{UK})$ was added. Immunoreactive proteins on the membrane were detected by using the ECL+ chemiluminescence detection kit (Amersham Pharmacia). Signals were quantified by densitometrically applying a commercial software package, Aida (Raytest, Straubenhardt, Germany). For subsequent analysis of total and phosphorylated MAPK, blots were stripped with $0 \cdot 2 \mathrm{M} \mathrm{NaOH}$ for $30 \mathrm{~min}$ at room temperature and then washed twice for 15 min with TBS-T before applying the standard immunodetection protocol.

\section{Results}

\section{IGFBP-2 binds to the cell surface via integrins}

Tracer displacement studies were performed to analyze qualitatively and quantitatively the binding of IGFBP-2 to the cell surfaces. On average, 30\% of the added recombinant ${ }^{125}$ I-labeled IGFBP-2 was bound tightly to the A673 cells. To determine the mode of ${ }^{125}$ I-labeled IGFBP-2 cell surface binding, attempts were made to displace the tracer from its binding site through addition of increasing concentrations of unlabeled hIGFBP-1, rhIGFBP-2, rhIGFBP-3, rhIGFBP-4, rhIGFBP-5 and rhIGFBP-6 (Fig. 1A), and of the human actin, insulin and albumin (Fig. 1B). ${ }^{125}$ I-labeled IGFBP-2 could be displaced only in a dosedependent manner by unlabeled IGFBP-1 (maximum: $50 \%$ displacement of totally bound) and by IGFBP-2 (44\%) from the surface of A673 cells. Both IGFBP-1 and IGFBP-2 contain the RGD (Gly-Arg-Asp) amino acid motif as a potential binding site for integrins. The IGFBPs containing no RGD motif, as well as the other proteins (Fig. 1B), were unable to displace ${ }^{125}$ I-labeled IGFBP-2.

In order to investigate the biochemical nature of the binding site on A673 cells, different antiintegrin antibodies raised against the heterodimeric proteins $\alpha 5 \beta 1, \alpha 1 \beta 1$ and $\alpha \mathrm{v} \beta 3$ were added to block the potential integrin-binding sites of IGFBP-2. A dose-dependent decrease of IGFBP-2 binding of up to $26 \cdot 0 \pm 1 \cdot 8 \%(P<0 \cdot 01)$ in A673 cells was measured after blocking the fibronectin receptor with anti- $\alpha 5 \beta 1$ antibody, while anti- $\alpha 1 \beta 1$ and anti- $\alpha v \beta 3$ antibodies had no effect (Table 1). As a control, fibronectin as a natural ligand of this specific $\alpha 5 \beta 1$ integrin could also displace the

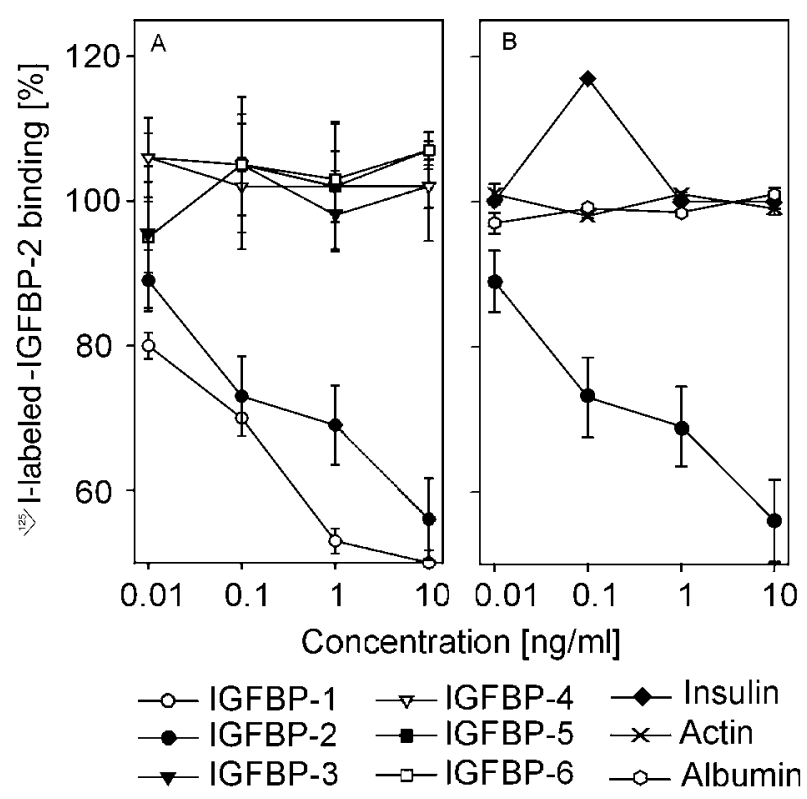

Figure 1 Displacement of IGFBP-2 tracer by different proteins. Detached and washed A673 cells $\left(5.0 \times 10^{6}\right)$ were incubated with ${ }^{125}$-labeled hIGFBP-2 and with other proteins as cell-surface binding competitor, as indicated. After $2 \mathrm{~h}$ incubation, cells were separated and washed, and the cell-associated radioactivity was counted. Data are shown as percent mean \pm S.D. compared with the control without competitor $(n=3)$.

Table 1 Influence of different antibodies $(250 \mathrm{ng} / \mathrm{ml})$ and fibronectin $(10 \mathrm{ng} / \mathrm{ml})$ on percent binding of totally bound IGFBP-2 tracer to A673 Ewing sarcoma cells relative to control $(100 \%)$. Data are means \pm S.D. of at least three repeated experiments

\begin{tabular}{lr} 
& $\%$ binding \\
\cline { 2 - 2 } Added protein & \\
Anti- $\alpha 5 \beta 1$ & $74 \pm 1 \cdot 8$ \\
Anti- $\alpha 1 \beta 1$ & $100 \pm 2 \cdot 1$ \\
Anti- $\alpha \mathrm{v} \beta 3$ & $99 \pm 2 \cdot 7$ \\
Fibronectin & $65 \pm 2 \cdot 5$ \\
\hline
\end{tabular}

${ }^{125}$ I-labeled IGFBP-2. The role of the RGD motif of IGFBP-2 for specific binding to the surface of A673 cells was studied in greater detail by the following experiment. As shown in Table 2, the synthetic RGD peptide was able to displace IGFBP-2 more strongly than a control RGE (Gly-Arg-Glu) peptide. In a subset of experiments, we also studied the effects of complexation of IGFBP-2 $(100 \mathrm{ng} / \mathrm{ml})$ on its specific binding to the cell surface, by using different amounts $(0 \cdot 01$ and $10 \mathrm{ng} / \mathrm{ml}$ ) of IGF-I and IGF-II (Table 2). As a major result, binding of $\mathrm{I}^{125}$-IGFBP-2 was partly 
Table 2 Influence of RGD motif and different IGFs on cell-surface binding of IGFBP-2 tracer to A673 Ewing sarcoma cells relative to untreated control (100\%). Data are means \pm S.D. of three repeated experiments

\section{Added protein/peptide}

RGD peptide $(1 \mu \mathrm{g} / \mathrm{ml})$

RGE peptide $(1 \mu \mathrm{g} / \mathrm{ml})$

IGFBP-2 (100 ng/ml)

IGFBP-2 $(100 \mathrm{ng} / \mathrm{ml})+$ IGF-I $(10 \mathrm{pg} / \mathrm{ml})$

IGFBP-2 $(100 \mathrm{ng} / \mathrm{ml})+$ IGF-I $(10 \mathrm{ng} / \mathrm{ml})$

IGFBP-2 $(100 \mathrm{ng} / \mathrm{ml})+$ IGF-II $(10 \mathrm{pg} / \mathrm{ml})$

IGFBP-2 (100 ng/ml)+IGF-II (10 ng/ml)
$\%$ binding

$67 \pm 3 \cdot 2$

$82 \pm 1 \cdot 7$

$43 \pm 5 \cdot 3$

$92 \pm 3 \cdot 0$

$91 \pm 4.9$

$103 \pm 6 \cdot 4$

$83 \pm 4.9$

obstructed after being complexed with either IGF-I or IGF-II.

For further study of the biologic effects of IGFBP-2 binding to the cell surface, a second cell model, the breast cancer cell-line Hs578T, was introduced. This cell line also expresses an $\alpha 5 \beta 1$ integrin and has weak IGF-I and IGF-II expression, but no endogenous IGFBP-2 expression (data not shown). Moreover, Hs578T cells contain no functional IGF-I receptor (Gill et al. 1997). This latter feature was assumed to allow the investigation of effects of IGFBP-2 independently of the IGF-I receptor signaling. The IGFBP-2 binding characteristics were similar to those observed for the A673 cells (summarized in Table 3). Thus, IGFBP-2 bound to Hs578T cells can be specifically displaced by anti- $\alpha 5 \beta 1$ integrin antibodies and by fibronectin. Furthermore RGD peptides and IGFBP-2 itself, but not RGE peptides, were able to displace IGFBP-2 tracer effectively.

\section{FAK is dephosphorylated after IGFBP-2 binding}

For study of the effects of IGFBP-2 binding to integrin on FAK, two different strategies were followed. In the case of A673 cells, which produce a high amount of IGFBP-2, we decreased the availability of the locally produced IGFBP-2 by using two different concentrations of a monoclonal anti-IGFBP-2 antibody. For the cell line Hs578T, which produces no IGFBP-2, we added increasing concentrations of recombinant IGFBP-2. In the latter experimental setting, addition of IGFBP-1, RGD and RGE peptides served as a control.

Table 3 Specificity of IGFBP-2 tracer binding to cell surfaces of Hs578T breast cancer cells. Data are means \pm S.D. of at least three repeated experiments relative to the control $(100 \%)$

\section{Added protein/peptide \\ Anti- $\alpha 5 \beta 1(250 \mathrm{ng} / \mathrm{ml})$ \\ RGD peptide $(10 \mu \mathrm{g} / \mathrm{ml})$ \\ RGE peptide $(10 \mu \mathrm{g} / \mathrm{ml})$ \\ IGFBP-2 (100 ng/ml) \\ Fibronectin $(10 \mathrm{ng} / \mathrm{ml})$}

\section{$\%$ binding}

$38 \pm 15 \cdot 2$

$80 \pm 10 \cdot 1$

$103 \pm 4 \cdot 4$

$65 \pm 4 \cdot 3$

$72 \pm 19 \cdot 2$

Furthermore, the phosphorylation level of FAK was studied by two different experimental approaches, as shown in Fig. 2A and B: (1) immunoprecipitation of tyrosine-phosphorylated (pTyr) proteins by using an $\alpha$-phosphotyrosine monoclonal antibody (mAb), followed by detection of phosphorylated FAK through immunoblot; (2) immunoprecipitation of total FAK by using the $\alpha$-FAK mAb, and then sequential detection of phosphorylated FAK by immunolot using antipTyr mAb, and total FAK by anti-FAK mAb. Both approaches yielded consistent results (Fig. 2A and B). In detail, incubation of Ewing sarcoma cells with anti-IGFBP-2 mAb caused a dose-dependent maximum increase of the phosphorylation level of FAK of $46 \%(P \leq 0 \cdot 05$; Mann-Whitney-U test $)$. In agreement with these findings, the addition of IGFBP-2 to Hs578T cells caused a decrease in the phosphorylation level of FAK of $47 \%(P \leq 0 \cdot 01)$. The results were confirmed when IGFBP-1 and a RGD peptide were used as positive controls, and the RGE peptide as a negative control.

\section{MAPK is dephosphorylated upon IGFBP-2 binding}

For study of the MAPK phosphorylation status as affected by IGFBP-2, both cell lines were stimulated by addition of rhIGFBP-2. The experimental setting was also necessary in the case of the A673 cells, since addition of an anti-IGFBP-2 antibody, and therefore a withdrawal of endogenous IGFBP-2, resulted in inconsistent data, probably because the change of the phosphorylation status of the MAPK is very fast $(5 \mathrm{~min})$ and the establishment of the equilibrium with an antibody is relatively slow and therefore not suitable. Incubation of the A673 cells with 


\section{A Ewing Sarcoma A673}

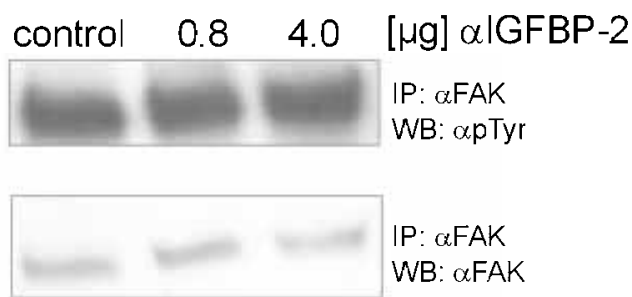

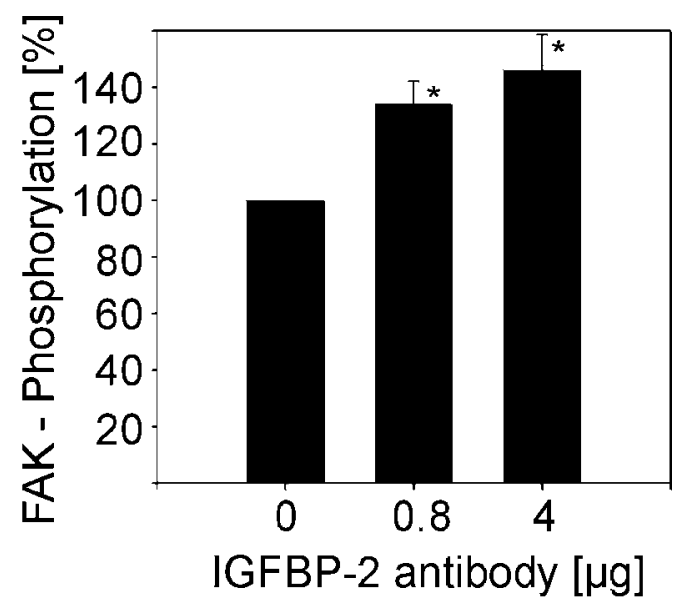

Figure 2 Influence of IGFBP-2 on FAK phosphorylation. Serum-starved cells were incubated with different amounts of anti-IGFBP-2 antibody (A) or IGFBP-2 (B) for $30 \mathrm{~min}$ at $37^{\circ} \mathrm{C}$, and then relative phosphorylation level of focal adhesion kinase (FAK) was determined as described in Materials and methods. Data are shown as mean \pm S.D. $\left(P \leq 0.05\left(^{*}\right) ; P \leq 0.01\left(^{* *}\right)\right)$, and two exemplary blots are presented $(n=7$; for IGFBP-1, $\left.n=2)\right)$.

IGFBP-2 resulted in a significant decrease of MAPK phosphorylation (Fig. 3A). At higher concentrations, no significant effect of IGFBP-2 was detectable, although there was a tendency towards less dephosphorylation. In Hs578T cells, similar effects of IGFBP-2 (Fig. 3B) were observed, that is, a dose-dependent decrease of the phosphorylation level, but no inverse effect of higher IGFBP-2 concentrations could be observed.

\section{Cell adhesion and proliferation are decreased after IGFBP-2 cell-surface binding}

An observation in the course of early experiments with A673 cells was an increasing number of detached cells, with the increase of the pericellular concentration of IGFBP-2 (data not shown). It was assumed that IGFBP-2 affects cell adhesion, possibly by way of the integrin signaling. 


\section{A Ewing Sarcoma A673}

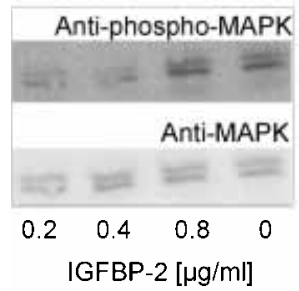

B Breast cancer Hs578T
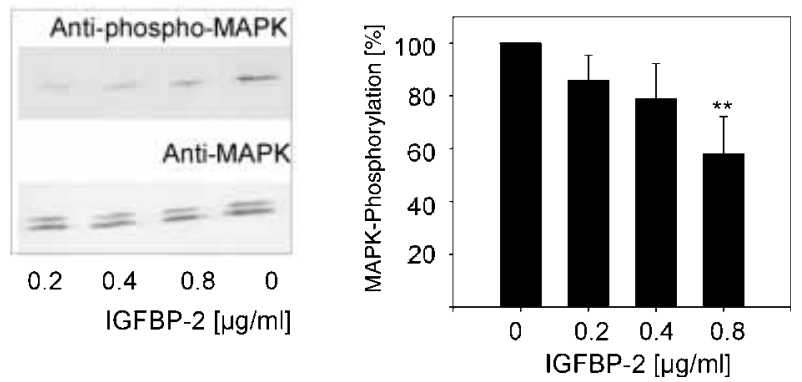

Figure 3 Influence of IGFBP-2 on MAPK phosphorylation. Serum-starved cells were incubated with different amounts of IGFBP-2 for $5 \mathrm{~min}$ at $37^{\circ} \mathrm{C}$, and then relative phosphorylation level of MAPK was determined as described in Materials and methods. Data are shown as mean \pm S.D. $\left(P \leq 0.05\left(^{*}\right), P \leq 0.02\left({ }^{* *}\right)\right.$, $\left.\left.P \leq 0.01{ }^{(\star \star}\right)\right)$, and two exemplary blots are shown $(n=7)$.

Similar effects could be mimicked in Hs578T cells through addition of increasing amounts of exogenous IGFBP-2. It was found that IGFBP-2 $(+30 \%, P \leq 0.05)$, as well as the RGD-containing peptide $(+80 \%, P \leq 0.05)$, but not the RGEcontaining peptide, promoted the de-adhesion of the cells in a dose-dependent manner (Fig. 4). The de-adhesion was diminished through incubation of A673 cells with an anti-IGFBP-2 mAb (not shown). Moreover, the addition of IGFBP-2 or RGD peptide inhibited significantly the proliferation of Hs578T cells, measured as $\left[{ }^{3} \mathrm{H}\right]$ thymidine incorporation, by up to $34 \%(P \leq 0 \cdot 05$; Fig. 5) as compared with untreated controls. The RGE peptide was ineffective in this respect.

\section{Discussion}

There is increasing evidence that IGFBP-2 expression correlates with the grade of malignancy

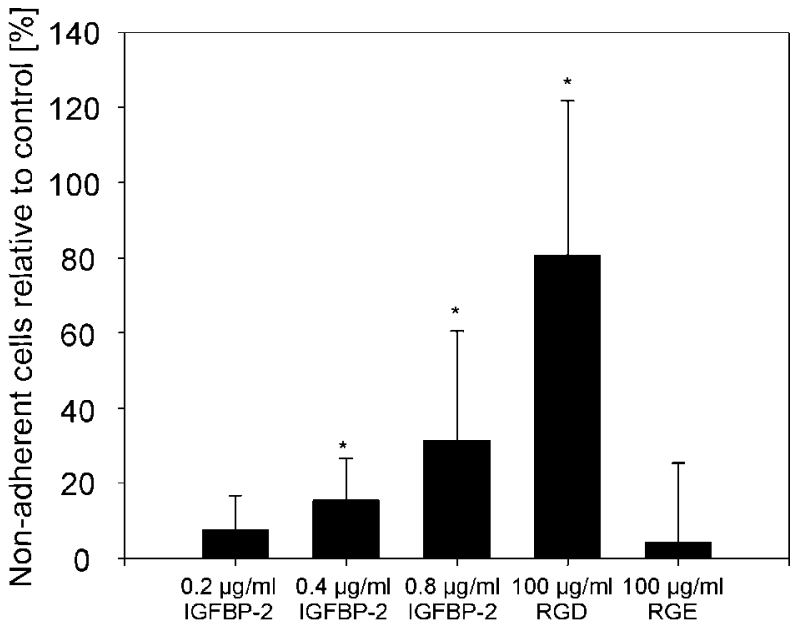

Figure 4 IGFBP-2-induced cell detachment. 24-h serum-starved Hs578T breast cancer cells were incubated with indicated substances for $24 \mathrm{~h}$. After incubation, the number of nonadherent cells was determined by counting cells. The number of detached cells is shown as percent mean \pm S.D. compared with control $\left(P \leq 0.05\left(^{*}\right)(n=10)\right)$.

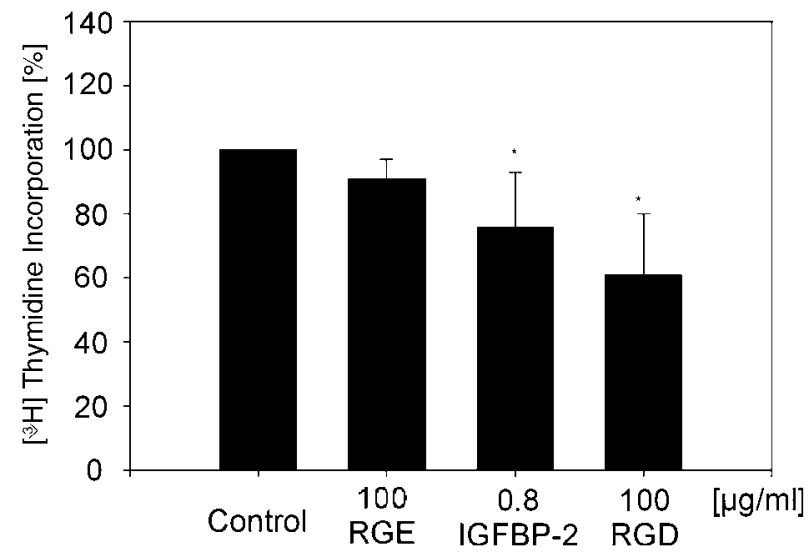

Figure 5 IGFBP-2 influence on proliferation. A total of 20000 Hs578T cells were seeded into 96-well plates, and indicated substances were added. After $24 \mathrm{~h}, 1 \mu \mathrm{Ci}$ $\left[{ }^{3} \mathrm{H}\right]$ thymidine was added, and a further incubation period of 3 days followed. The incorporated radioactivity was counted. Data are shown as mean \pm S.D. percentage of radioactivity incorporated compared with untreated control cells $\left(P \leq 0.05\left(^{*}\right)(n=3\right.$ in triplicate $\left.)\right)$.

in many solid tumors (Kanety et al. 1993, Miller et al. 1994, Ho \& Baxter 1997, Boulle et al. 2001, Elmlinger et al. 2001a). In addition, a number of reports have also highlighted the function of IGFBP-2 in tumors as regulator of the mitogenicity of locally produced IGFs and as a survival factor 
(Oh \& Rosenfeld 1999, Hoeflich et al. 2000a). However, the causal relationship between IGFBP-2 expression and tumor progression has not been investigated on a cellular level. More specifically, the potential of IGFBP-2, which has been shown to bind to cell surfaces of cancer cells (Arai et al. 1995, Russo et al. 1999), to elicit a cellular response directly, independently of IGF-I receptor activation, has not been determined.

In the present study we have described the mechanism of a direct, that is, not IGF-I receptor-dependent, action of IGFBP-2 through the signaling pathway of the $\alpha 5 \beta 1$ integrin. Our results demonstrate for the first time that IGFBP-2, by means of its RGD-peptide motif, can specifically bind to the $\alpha 5 \beta 1$ integrin on the cell surface. Thereby, IGFBP-2 triggers the integrin signaling pathway and hinders cell proliferation, while simultaneously promoting de-adhesion of tumor cells.

The comparison of the Ewing sarcoma cell line A673, which does produce IGFBP-2 and expresses IGF-I receptors, and the breast cancer cell line Hs578T, which neither produces IGFBP-2 nor expresses functional IGF-I receptors (Gill et al. 1997), proves that these effects are independent of IGF. Similar cellular binding and signal transduction have been described for IGFBP-1, which also contains an RGD motif (Perks et al. 1999). However, the IGF-independent effects of IGFBP-2 may be crucial to the understanding of the pathophysiology of solid tumors, firstly because tumor cells produce by far more IGFBP-2 than IGFBP-1, and secondly because IGFBP-2 expression often correlates with clinical parameters of malignancy in tumors.

The regulation of the IGFBP-2 expression by locally produced IGFs indicates that tumor cells themselves can produce large quantities of this protein to modulate the mitogenic and antiapoptotic potential of the tumor-derived IGFs. So far, the antiproliferative effect of IGFBP-2 has been explained by the 'IGF-I receptor competitive' action of IGFBP-2. However, IGFBP-2 has been shown to have a stimulatory effect on proliferation in some distinct cell-culture models (Chen et al. 1994, Slootweg et al. 1995, Hoeflich et al. 2000a), and the tumor-promoting effects of IGFBP-2 have also been discussed (for a review, see Hoeflich et al. $2000 b$ ). Our study clearly demonstrates that in our case the antiproliferative effect found for IGFBP-2 is at least partially mediated by the IGFindependent action of IGFBP-2, which, via the RGD motif, interacts with the integrin receptor at the cell surface and subsequently activates the integrin signaling cascade. The increased availability of IGFBP-2 could therefore evoke biologic actions itself, an effect which may explain, depending on the cell model used, antiproliferative as well as stimulatory effects. The dephosphorylation of the FAK and MAPK species after RGD-specific binding of IGFBP-2 found in our study, and the subsequent effects observed on proliferation and cell adhesion, are highly indicative of this biologic significance (Bates et al. 1995, Boudreau \& Jones 1999). Consistent with our results, McCaig et al. (2002) were able to show that IGFBP-2 can interact with the cell surface of Hs578T cells to inhibit directly cell-surface contacts in cell attachment assays. Whether this interaction is a result of the direct occupation of integrins or a triggering of integrin downstream signaling remains unclear. Alpha5 $\beta 1$-integrin, the fibronectinreceptor, has been identified as the binding site for IGFBP-2, whereas antibodies against other integrins, such as the $\alpha 1 \beta 1$ and $\alpha v \beta 3$, did not inhibit the binding to the Ewing sarcoma cell line A673. The binding site is thus identical with that of IGFBP-1 in breast-cancer cells (Perks et al. 1999), in trophoblasts (Irving \& Lala 1995, Irwin \& Giudice 1998) and in Chinese hamster ovary cells (Jones et al. 1995, Irwin \& Giudice 1998). It has been shown in all these studies that IGFBP-1 interaction via this integrin enhances migration, and regulation of cell invasion processes has been assumed. Consistently, our data on IGFBP-2 in the context of cell adhesion and proliferation and the fact that IGFBP-2 expression is often elevated in tumors strongly support the assumption that this IGFbinding protein is involved in the migration and invasiveness of tumor cells.

After ligand binding, the intergrins which possess no kinase activity form focal complexes through interaction of their intrinsic domain with FAK, resulting in FAK autophosphorylation. The coprecipitation of further components of these complexes, such as src and paxillin, indicates their connection to intracellular signaling pathways such as MAPK (Schaller et al. 1995, Hauck et al. 2001). Similar effects, such as an influence on the apoptosis of breast cancer cells, have been shown for IGFBP-1 (Perks et al. 1999). Whether the 
previously found binding of IGFBP-2 to glycosaminoglycans (Arai et al. 1995) and proteoglycans (Russo et al. 1997, 1999) of the extracellular matrix (EGM) is also involved in this integrin signaling is still unclear. However, RGDindependent activation of the integrin signaling cascade is also possible, as demonstrated for the protein CTGF (Chen et al. 2001), also known as IGFBP-rP2. Similar intrinsic mechanisms have been hypothesized for other IGFBPs (Perks \& Holly 1999, McCaig et al. 2002). Recently, it was demonstrated for CYR61, another member of the IGFBP superfamily, that cell-surface interaction of this protein with integrins required a simultaneous proteoglycan interaction (Chen et al. 2000, Grzeszkiewicz et al. 2002). One can thus speculate that in some cases IGFBP-2 may act on integrin signaling through synergistic binding to two different binding sites. In analogy to GYR61 cell-surface interaction (Chen et al. 2000), proteoglycan interaction of IGFBP-2 can also lead to differential concomitant integrin subtype specificity mediated via its RGD motif. Consideration must, however, be given to the fact that the binding of IGFBP-2 to the ECM via heparin was possible only after complexing with a surplus of IGF-I or IGF-II (Arai 1995), whereas, in contrast, the binding to integrins described here was partly inhibited by equimolar quantities of IGFs. This dependency on IGF complexing suggests that the integrin binding can be regulated by high concentrations of IGF. A significant paracrine effect on tumor cells is thus possible only with production of a molar surplus of IGFBP-2 over IGF-I+IGF-II.

In conclusion, these non-IGF-I receptordependent effects on proliferation and adhesion of both tumor cell lines through integrin signaling indicate that the correlation between increased IGFBP-2 expression and higher clinical grades of malignancy of tumors is neither a coincidence nor a mere epiphenomenon. It is very likely that the loosening of cell adhesion caused by increased IGFBP-2, through direct binding and/or through integrin signaling, contributes to tumor cell dissemination and thus to tumor progression.

\section{Acknowledgements}

We thank Karin Weber for technical assistance and David Martin, MD, for his help with the manuscript. The work was supported by grants from the German Research Council (DFG 167/3-2) and ForTüne, and by the Growth Research Center of Tuebingen.

\section{References}

Arai T, Busby W \& Clemmons DR 1995 Binding of insulin-like growth factor (IGF) I or II to IGF-binding protein-2 enables it to bind to heparin and extracellular matrix. Endocrinology 137 $4571-4575$.

Bates RC, Lincz LF \& Burns GF 1995 Involvement of integrins in cell survival. Cancer Metastasis Reviewes 14 191-203.

Boudreau NJ \& Jones PL 1999 Extracellular matrix and integrin signalling; the shape of things to come. Biochemical fournal $\mathbf{3 3 9}$ 481-488.

Boulle N, Baudin E, Gicquel C, Logie A, Bertherat J, Penfornis A, Bertagna X, Luton JP, Schlumberger M \& Le Bouc Y 2001 Evaluation of plasma insulin-like growth factor binding protein-2 as a marker for adrenocortical tumors. European fournal of Endocrinology 144 29-36.

Chen CG, Chen N \& Lau LF 2001 The angiogenic factors Cyr61 and connective tissue growth factor induce adhesive signaling in primary human skin fibroblasts. Fournal of Biological Chemistry 276 10443-10452.

Chen JC, Shao ZM, Sheikh MS, Hussain A, LeRoith D, Roberts CT Jr \& Fontana JA 1994 Insulin-like growth factor binding protein enhancement of insulin-like growth factor-I (IGF-I)-mediated DNA synthesis and IGF-I binding in human breast carcinoma cell line. Fournal of Cellular Physiology 158 69-78.

Chen N, Chen CG \& Lau LF 2000 Adhesion of human skin fibroblasts to Cyr61 is mediated through integrin $\alpha 6 \beta 1$ and cell surface heparan sulfate proteoglycans. Fournal of Biological Chemistry 275 24953-24961.

Clemmons DR 1997 Insulin-like growth factor binding proteins and their role in controlling IGF actions. Cytokine and Growth Factor Revieres 8 45-62.

Duguay SJ, Jin Y, Stein J, Duguay AN, Gardener P \& Steiner DF 1998 Posttranslational processing of insulin-like growth factor-2 precursor. Fournal of Biological Chemistry 273 18443-18451.

Elmlinger MW, Rauschnabel U, Koscielniak E, Weber K \& Ranke MB 1999 Secretion of noncomplexed 'big' (10-18 kDa) forms of insulin-like growth factor-II by 12 soft tissue sarcoma cell lines. Hormone Research 52 178-185.

Elmlinger MW, Bell M, Schütt BS, Langkamp M, Kutoh E \& Ranke MB $2001 b$ Transactivation of the IGFBP-2 promoter in human tumor cell lines. Molecular and Cellular Endocrinology 175 211-218.

Elmlinger MW, Deininger MH, Schuett BS, Meyermann R, Duffner F, Grote EH \& Ranke MB 2001 a In vivo expresssion of insulin-like growth factor-binding protein-2 in human gliomas increases with the tumor grade. Endocrinology 142 1652-1658.

Firth SM \& Baxter RC 2002 Cellular actions of the insulin-like growth factor binding proteins. Endocrine Reviews 23 824-854.

Gill ZP, Perks CM, Newcomb PV \& Holly JMP 1997 Insulin-like growth factor-binding protein (IGFBP-3) predisposes breast cancer cells to programmed cell death in a non-IGF-dependent manner. Fournal of Biological Chemistry 272 25602-25607.

Grzeszkiewicz TM, Lindner V, Chen N, Lam SC-T \& Lau LF 2002 The angiogenic factor cysteine-rich 61(CYR61, CGN1) supports vascular smooth muscle cell adhesion and stimulates chemotaxis through integrin $\alpha 6 \beta 1$ and cell surface heparan sulfate proteoglycans. Endocrinology 143 1441-1450.

Hauck CR, Hunter T \& Schlaepfer DD 2001 The v-Scr SH-3 
domain facilitates a cell adhesion-independent association with FAK. Fournal of Biological Chemistry 276 17653-17662.

Ho PJ \& Baxter RC 1997 Insulin-like growth-factor-binding protein-2 in patients with oristate carcinoma and benign prostatic hyperplasia. Fournal of Clinical Endocrinology and Metabolism 79 428-434.

Hoeflich A, Fettscher O, Lahm H, Blum WF, Kolb HJ, Engelhardt D, Wolf E \& Weber MM $2000 a$ Overexpression of insulin-like growth factor-binding protein-2 results in increased tumorigenic potential in Y-1 adrenocortical tumor cells. Cancer Research $\mathbf{6 0}$ $834-838$.

Hoeflich A, Reisinger R, Lahm H, Kiess W, Blum W, Kolb HJ, Weber MM \& Wolf E $2000 b$ Insulin-like growth factor binding protein 2 in tumorigenesis: protector or promotor? Cancer Research $618601-8610$.

Irving JA \& Lala PK 1995 Functional role of cell surface integrins on human trophoblast cell migration: regulation by TGF- $\beta$, IGF-II and IGFBP-1. Experimental Cell Research 217 419-427.

Irwin JC \& Giudice LC 1998 Insulin-like growth factor binding protein- 1 binds placental cytotrophoblast alpha5 betal integrin and inhibits cytotrophoblast invasion into decidualized endometrial stromal cultures. Growth Hormone and IGF Research 8 21-31.

Jones JI, Gockerman A, Busby WB, Wright G \& Clemmons DR 1993 Insulin-like growth factor binding protein 1 stimulates cell migration and binds to the $\alpha 5 \beta 1$ integrin by means of its Arg-Gly-Asp sequence. PNAS 90 10553-10557.

Jones JI, Doerr ME \& Clemmons DR 1995 Cell migration: interactions among integrins, IGFs and IGFBPs. Progress in Growth Factor Research 6 319-327.

Kanety H, Madajar Y, Dagan Y, Levi J, Papa MZ, Pariente C, Goldowa B \& Karasik A 1993 Serum insulin-like growth factor-binding protein-2 (IGFBP-2) is increased and IGFBP-3 is decreased in patients with prostate cancer: correlation with serum prostate-specific antigen. Fournal of Clinical Endocrinology and Metabolism 77 229-233.

McCaig C, Perks CM \& Holly JMP 2002 Intrinsic actions of IGFBP-3 and IGFBP-5 on Hs578T breast cancer epithelial cells: inhibition or accentuation of attachment and survival is dependent upon the presence of fibronectin. Fournal of Cell Science $\mathbf{1 1}$ 4293-4303.
Miller HL 1994 Insulin-like growth factor-binding protein-2 concentrations in cerebrospinal fluid and serum of children with malignant solid tumors or acute leukemia. Fournal of Clinical Endocrinology and Metabolism 83 1713-1720.

Oh Y \& Rosenfeld RG 1999 IGF-independent actions of the IGF binding proteins. In The IGF System, pp 257-272. Eds RG Rosenfeld \& CT Roberts Jr. Totowa, NJ: Humana Press p 10.

Perks CM \& Holly JMP 1999 Insulin-like growth factor binding protein-3 (IGFBP-3) modulates the phosphorylation of focal adhesion kinase (FAK) independently of IGF in Hs578T human breast cancer cells. Growth Hormone and IGF Research 9369.

Perks CM, Newcomb PV, Norman MR \& Holly JMP 1999 Effect of insulin-like growth factor binding protein-1 on integrin signalling and the induction of apoptosis in human breast cancer cells. Fournal of Molecular Endocrinology 22 141-150.

Ruoslahti E 1999 Fibronectin and its integrin receptors in cancer. Advances in Cancer Research 76 1-20.

Russo VC, Bach LA, Fosang AJ \& Werther GA 1997 Insulin-like growth factor binding protein-2 (IGFBP-2) binds to cell surface proteoglycans in rat brain olfactory bulb. Endocrinology 138 $4858-4867$.

Russo VC, Backer N, Bach LA, Fosang AJ \& Werther GA 1999 FGF-induces proteolysis of secreted and cell membrane-associated IGF binding protein-2 in human neuroblastoma cells. Endocrinology $1403082-3090$.

Schaller MD, Otey CA, Hildebrand JD \& Parsons JT 1995 Focal adhesion kinase and paxillin bind to peptides mimicking $\beta$ integrin cytoplasmic domains. Fournal of Cell Biology 130 1181-1187.

Slootweg MC, Ohlsson C, Salles JP, deVries CP \& Netelenbos JC 1995 Insulin-like growth factor binding protein-2 and -3 stimulate growth hormone receptor binding and mitogenesis in rat osteosarcoma cells. Endocrinology 136 4210-4217.

Yang CQ, Zhan X, Hu X, Kondepudi A \& Perdue JF 1996 The expression and characterisation of human recombinant proinsulin-like growth factor-2 precursor. Endocrinology 137 2766-2773.

Received in final form 11 December 2003 Accepted 5 January 2004 